Article

\title{
Ability of Euscelidius variegatus to Transmit Flavescence Dorée Phytoplasma with a Short Latency Period
}

\author{
Luca Picciau $^{1}$, Bianca Orrù ${ }^{1}$, Mauro Mandrioli ${ }^{2}\left(\mathbb{D}\right.$, Elena Gonella ${ }^{1, *(D)}$ and Alberto Alma ${ }^{1, *}$ \\ 1 Dipartimento di Scienze Agrarie, Forestali e Alimentari (DISAFA), University of Torino, \\ I-10095 Grugliasco (TO), Italy; luca.picciau@unito.it (L.P.); bianca.orru@unito.it (B.O.) \\ 2 Dipartimento di Scienze della Vita (DSV), University of Modena e Reggio Emilia, I-41125 Modena, Italy; \\ mauro.mandrioli@unimore.it \\ * Correspondence: elena.gonella@unito.it (E.G.); alberto.alma@unito.it (A.A.)
}

Received: 5 August 2020; Accepted: 1 September 2020; Published: 5 September 2020

check for updates

Simple Summary: Phytoplasmas are a group of phloem-restricted phytopathogens that attack a huge number of wild and cultivated plants, causing heavy economic losses. They are transmitted by phloem-feeding insects of the order Hemiptera; the transmission process requires the vector to orally acquire the phytoplasma by feeding on an infected plant, becoming infective once it reaches the salivary glands after quite a long latency period. Since infection is retained for all of the insect's life, acquisition at the nymphal stage is considered to be most effective because of the long time needed before pathogen inoculation. This work provides evidence for the reduced latency period needed by adults of the phytoplasma vector Euscelidius variegatus from flavescence dorée phytoplasma acquisition to transmission. Indeed, we demonstrate that adults can become infective as soon as 9 days from the beginning of phytoplasma acquisition. Our results support a reconsideration of the role of adults in phytoplasma epidemiology, by indicating their extended potential ability to complete the full transmission process.

\begin{abstract}
Phytoplasma transmission takes place by insect vectors through an Acquisition Access Period (AAP), Latency Period (LP) and Inoculation Access Period (IAP). Generally, phytoplasmas are believed to be transmitted more efficiently by nymphs because they need a long LP to reach the salivary glands before becoming infective. The transmission can start from adults as well, but in this case a long LP may exceed the insect's lifespan. However, previous evidence has indicated that adults can undergo a shorter LP, even though little knowledge is available regarding the phytoplasma temporal dynamics during this period. Here, we investigate the minimum time required by the phytoplasma to colonize the vector midgut and salivary glands, and finally to be inoculated into a plant. We used the leafhopper Euscelidius variegatus to investigate the life cycle of flavescence dorée phytoplasma (FDP). Phytoplasma-free E. variegatus adults were left on broad beans (BBs) infected with FDP for an AAP of 7 days. Subsequently, they were individually transferred onto a healthy BB for seven different IAPs, each one lasting $24 \mathrm{~h}$ from day 8 to 14 . Molecular analyses and fluorescence in situ hybridization were performed for FDP detection. FDP was found in the leafhopper midgut from IAP 1 with an infection rate reaching $50 \%$, whereas in the salivary glands it was found from IAP 2 with an infection rate reaching 30\%. FDP was also detected in BBs from IAP 4, with infection rates reaching $10 \%$. Our results represent an important step to further deepen the knowledge of phytoplasma transmission and its epidemiology.
\end{abstract}

Keywords: vector; acquisition by adults; latency period; transmission process; midgut; salivary glands; phytoplasma epidemiology 


\section{Introduction}

Phytoplasmas are phloem-limited, wall-less bacteria of the class Mollicutes, associated with diseases affecting over one thousand cultivated and wild plant species [1]. Phytoplasma diseases in general are known and described throughout almost the entire world, although the different groups and subgroups are not evenly distributed geographically [2]. They are associated with many plants, both herbaceous and woody [3]; the symptoms attributable to these pathogenic agents are usually flower malformation (virescence, phyllody), yellowing, stunting, growth aberration, and decline [4]. Their relevance in agriculture has increased over the last few decades, and many diseases are now identified as related to phytoplasmas. In Europe, some of the most economically important diseases are grapevine yellows (flavescence dorée, FD; bois noir, BN); fruit-tree phytoplasmoses (apple proliferation, AP; pear decline, PD; European stone fruit yellows, ESFY); and stolbur (STOL) [5].

A special trait of the phytoplasma life cycle is their obligate interaction with plant and insect hosts; however, such a multi-actor interplay is still poorly investigated. In particular, understanding of the transmission process from vectors to plants is an essential step to figure out the epidemiology of the associated diseases [6], in order to develop suitable protection strategies. Phytoplasmas are transmitted in nature by hemipteran phloem-feeding insects belonging to the families Cicadellidae (leafhoppers), Cixiidae (planthoppers), and Psyllidae (psyllids) [7]. More than 75\% of the known leafhopper vector species are included in the Cicadellidae subfamily Deltocephalinae; however, a number of vector species are also present within other subfamilies [8,9].

Phytoplasma transmission occurs by insect vectors through a set of peculiar phases, according to the persistent-propagative modality. The Acquisition Access Period (AAP) is the first one, which occurs when an insect feeds on an infected host plant. Concerning the life stage, nymphs are more efficient than adults in acquiring phytoplasmas [10] and show a longer period of infectivity before insect death, thus increasing phytoplasma spread. However, first-instar nymphs of Macrosteles fascifrons (Stål) and Euscelidius variegatus (Kirschbaum) are less likely to acquire phytoplasmas than older nymphs and adults, probably because of their short stylets [11,12]. Likewise, first-instar nymphs of Scaphoideus titanus Ball do not feed into the phloem of grapevine [13] and therefore are unable to acquire the phytoplasmas.

A Latency Period (LP) or incubation is needed for vectors before being able to transmit phytoplasmas to plants. At the end of the LP, the last phase takes place, called the Inoculation Access Period (IAP). During the LP, phytoplasmas cross the midgut epithelium to reach the hemolymph and actively multiply, colonizing the insect body, including the salivary glands [9,14]. The LP varies from a minimum of 12-14 days-in Circulifer tenellus (Baker) and beet leafhopper-transmitted virescence (BLTV) phytoplasma, and in S. titanus and FD phytoplasma (FDP) - to more than 21 days or even over a month in other cases [4,15-20]. The duration of the LP is characteristic for each vector-phytoplasma association. For example, differences in the infection temporal dynamics were demonstrated for E. variegatus, a lab vector, infected at the same time by FDP and Chrysanthemum Yellows phytoplasma (CYP) [21]. Differences in LP duration-i.e., in the time required to reach the insect's salivary glands-are related to the host range width of different phytoplasmas, and to the co-evolution between insects and phytopathogens. Indeed, newly established associations may result in high immune activation in the insect midgut and hemolymph [22,23]. Even though the AAP may take place both in juveniles and adults [19], acquisition by nymphs can be more effective for the spread of phytoplasmas in the field when the LP is long, since acquisition by adults can result in a short period of infectivity before insect death [24]. Nonetheless, limited knowledge is available concerning the real LP occurring in adults, even though previous evidence has indicated that when acquisition occurs in adults, a shorter LP is needed, suggesting that the role of field specimens that acquire as adults may not be negligible [19].

The aim of this research was to assess the temporal dynamics of the phytoplasma transmission process, starting the AAP with adult specimens, identifying the minimum period required for phytoplasma to infect the insect midgut and salivary glands, and the shortest LP with successful 
transmission that can be recorded. For this purpose, we used an experimental pathosystem composed of E. variegatus as a vector, the broad bean as a host plant, and FDP [25].

\section{Materials and Methods}

\subsection{Insect and Plant Material}

A healthy colony of E. variegatus was maintained under laboratory conditions on oat plants (Avena sativa L., cv Aveny) in a climatic chamber at $25^{\circ} \mathrm{C}$, photoperiod $16 \mathrm{~L}: 8 \mathrm{D}$, in order to obtain phytoplasma-free specimens. Insects were bred until adult stage, and newly emerged adults (less than $24 \mathrm{~h}$ old) were used for transmission trials. A PCR assay was performed on a batch of 10 randomly chosen specimens from the colony to confirm phytoplasma absence prior to transmission tests. Broad beans (Vicia faba L. cv. Aguadulce, BBs) infected with FDP were obtained by exposing seedlings to E. variegatus specimens infected with FD-C phytoplasma (16SrV-C) [26]. Healthy broad bean seedlings were grown in screen houses separated from the insect rearing space and other phytoplasma sources.

\subsection{Transmission Experiments}

Transmission trials were set up in a climatic chamber $\left(T=25^{\circ} \mathrm{C}, \mathrm{RH}=75 \%\right.$, photoperiod $\left.16 \mathrm{~L}: 8 \mathrm{D}\right)$. Newly emerged adults of E. variegatus were caged on BB plants previously infected with FDP and checked for infection by quantitative PCR [25-27], for the AAP. The acquisition access period lasted 7 days.

After the AAP, insects were immediately used to perform seven different IAPs, called IAPs $1-7$, each one corresponding to the following 1 to 7 days and lasting $24 \mathrm{~h}$. Specifically, at day 8 , 40 adults of E. variegatus (20 males and 20 females) were sorted out and individually placed on a single healthy potted BB seedling caged inside a Plexiglas cylinder $(\mathrm{h}=20 \mathrm{~cm}$; diameter $=12 \mathrm{~cm})$ for $24 \mathrm{~h}$ to perform IAP 1 . The same procedure was used to perform IAP 2, but each insect was first transferred onto a single healthy BB seedling for a one-day LP at day 8 , and then moved onto another healthy BB seedling to perform IAP 2 at day 9. The scheme was repeated for the following IAPs, increasing the LP on the same BB by one day every time until IAP 7 at day 14 (Figure 1). Therefore, for each IAP, 40 E. variegatus adults were employed to inoculate $40 \mathrm{BBs}$ for $24 \mathrm{~h}$, after a variable LP performed on another 40 plants (with the exception of IAP 1, which had no LP). At the end of every IAP, insects were collected to isolate the midgut and salivary glands, using sterile forceps under a stereomicroscope (Figure 1). Dissected tissues were stored at $-20{ }^{\circ} \mathrm{C}$ until use for molecular analyses to detect FDP presence. Inoculated plants were treated with an insecticide (Etofenprox, TREBON ${ }^{\circledR} \mathrm{UP}$, SIPCAM ITALIA S.p.A., Milan, Italy; $0.5 \mathrm{~mL} / \mathrm{L}$ ) and kept inside an insect-proof cage, in a climatic chamber, for three weeks from the beginning of phytoplasma inoculation. At the end of this period, the appearance of symptoms was recorded, and leaf vein samples were collected from all plants for molecular analyses. The same procedure was repeated for a second experiment, in order to perform fluorescence in situ hybridization (FISH) analysis. In this experiment, we selected only those IAPs where FDP colonization of salivary glands was previously observed by molecular diagnosis. Ten adults (five males and five females) were used for each IAP in this experiment. 


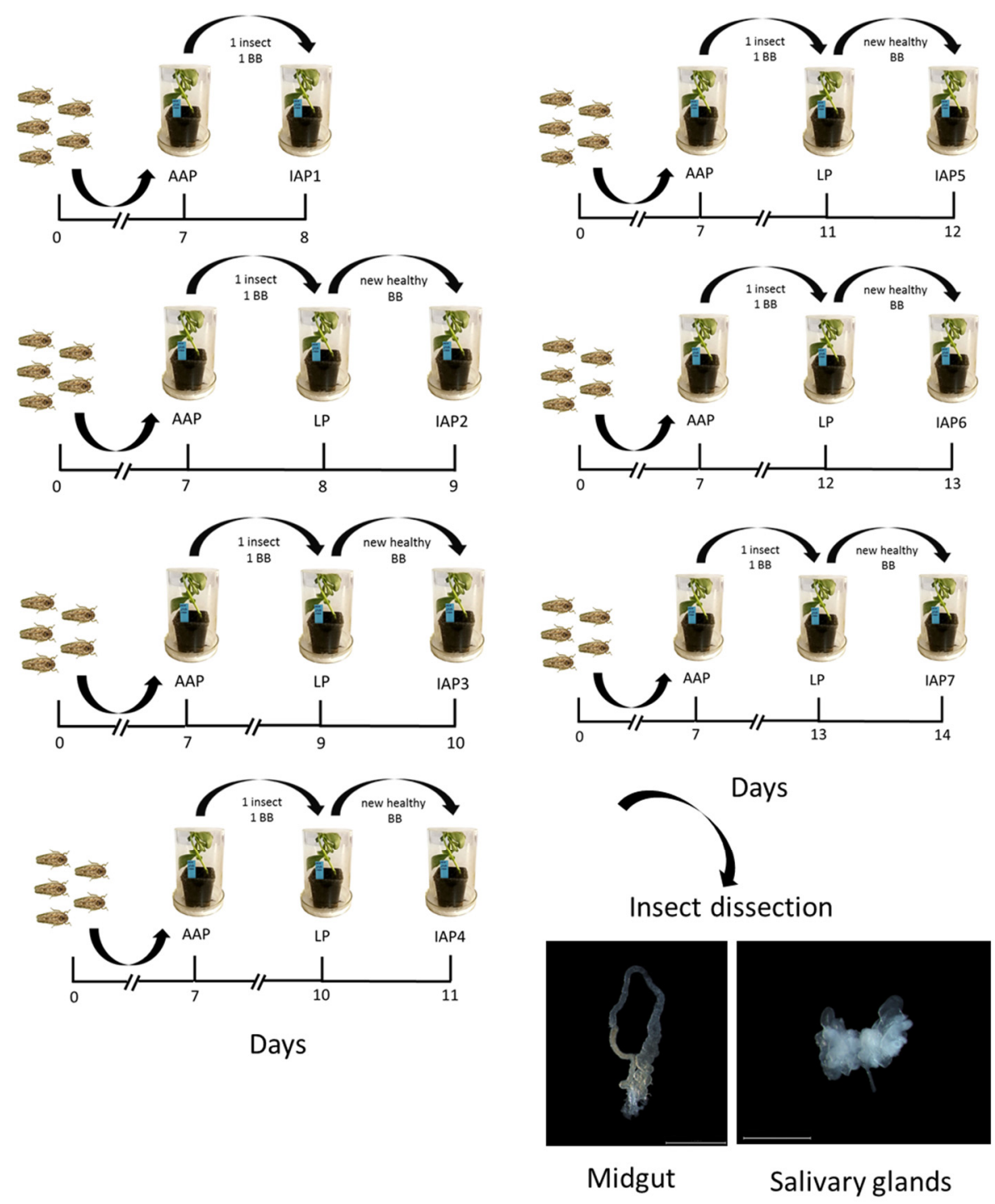

Figure 1. Experimental procedure followed for flavescence dorée phytoplasma (FDP) transmission trials. Adult E. variegatus specimens were exposed to an FDP-infected broad bean (BB) for an Acquisition Access Period (AAP) (day 0-7), then individually caged with a BB seedling for Latency Periods (LPs) of different durations ( 0 to 6 days). Finally, insects were moved onto a new healthy plant to perform a $24 \mathrm{~h}$ Inoculation Access Period (IAP) 1 to 7 days after the end of the AAP (IAP 1-7) $(n=40)$. At the end of the experiment (from day 8 for IAP 1 to day 14 for IAP 7), insects were collected and dissected to isolate the midgut and salivary glands for molecular or fluorescence in situ hybridization (FISH) analyses.

\subsection{DNA Extraction and Quantitative Real-Time PCR Analysis}

Total DNA extraction was performed separately from salivary glands and midguts dissected from single insects used in transmission experiments and from inoculated BBs. A protocol suitable for DNA extraction from leafhoppers was used for E. variegatus organs [28], with the following modification: DNA was resuspended in $20 \mu \mathrm{L}$ of TE buffer, $\mathrm{pH}$ 8. Plant DNA was extracted according to the DNeasy Plant Mini Kit protocol instructions (Qiagen, Milan, Italy), from leaf tissue previously grounded with liquid nitrogen in a sterile mortar.

Total DNA from insects and BBs was then submitted to quantitative real-time PCR (qPCR), in order to measure the presence and concentration of phytoplasma genome units (=cells) in those tissues. A CFX Connect ${ }^{\mathrm{TM}}$ Real-Time PCR Detection System (Bio-Rad, Richmond, CA, USA) was used with SsoAdvanced ${ }^{\mathrm{TM}}$ Universal SYBR ${ }^{\circledR}$ Green Supermix (Bio-Rad). Reactions targeting the $16 \mathrm{~S}$ rRNA gene of group $16 \mathrm{SrV}$ phytoplasmas were carried out on all samples by using the fAY/rEY 
primer pair [29,30], with the conditions described by Galetto et al. [31]. The average FDP Genome Units $(\mathrm{GU}) / \mu \mathrm{L}$ was calculated by dividing $16 \mathrm{~S}$ rRNA gene copy numbers by two, because this gene is estimated to be in double copy in the genome of phytoplasmas [32]. The obtained values were then multiplied by the final elution volume $(\mu \mathrm{L})$ of extracted DNA, i.e., by 20 (for insect organs) or by 100 (for plant samples), in order to obtain the absolute FDP GU/sample. An additional qPCR targeting the insect's $18 \mathrm{~S}$ rRNA was performed on gut and salivary gland samples, with the aim to normalize the absolute phytoplasma concentration. Primers MqFw/MqRv were used according to Marzachì and Bosco [33]. Normalized phytoplasma GU/sample was calculated per picogram of insect 18Sr RNA gene, whereas phytoplasma GU/sample from BBs was related to 100 milligrams of leaf. Serial dilutions of PCR-amplified 16S rRNA gene of FDP cloned with the pGEM ${ }^{\circledR}$-T Easy Vector Cloning Kit (Promega, Milan, Italy) were used to obtain standard curves. The detection limit was calculated as the lowest concentration of cloned amplicons used for standard curves that was successfully amplified and corresponded to $1.0 \times 10^{0} \mathrm{FDP}$ GU.

\subsection{Fluorescent In Situ Hybridization (FISH)}

Euscelidius variegatus midguts and salivary glands were obtained from adults used to perform those IAPs where qPCR analysis highlighted the presence of FDP in the salivary glands. Whole mount FISH analyses were then carried out on dissected tissues from these insects. Hybridizations were conducted with probe ph1298, specifically targeting group $16 \mathrm{SrV}$ phytoplasmas, labeled with Cy5 (indodicarbocyanine, absorption/emission at $650 / 670 \mathrm{~nm}$ ), as described by Lessio et al. [34]. Moreover, insect tissues were stained with DAPI (4', 6 -diamidino-2-phenylindole, absorption/emission at 358/461 $\mathrm{nm})$. Dissected organs were fixed for $2 \mathrm{~min}$ at $4{ }^{\circ} \mathrm{C}$ in $4 \%$ paraformaldehyde and washed in PBS. All hybridization experiment steps were performed following Gonella et al. [35]. After hybridization, the samples were mounted in antifading medium and then observed in a laser scanning confocal microscope SP2-AOBS (Leica Microsystems Srl, Buccinasco (MI), Italy).

\subsection{Statistical Analysis}

Statistical analyses were performed with SPSS Statistics $26^{\circledR}$ (IBM Corp. Released 2016, Armonk, NY, USA). Each single insect and the corresponding BB were considered as a separate replicate to calculate the FDP infection rate, infectivity rate and transmission rate corresponding to each IAP. Infection rates were expressed as the number of FDP-positive midguts, midguts + salivary glands, and BBs, respectively, as a proportion of the total number of samples $(n=40)$. The infectivity rates for E. variegatus were expressed as the number of infective insects (midguts + salivary glands) as a proportion of the infected ones (at least midgut infected). The transmission rates were expressed as the percentage of infective insects (with FDP-positive midguts + salivary glands) that corresponded to an infected BB. Infection, infectivity and transmission rates were compared using a generalized linear model (GLM) with a binomial probability distribution—with positive samples marked as " 1 ", and negative samples as " 0 " - and a Bonferroni post hoc test $(p<0.05)$. The average concentrations of phytoplasma cells corresponding to different IAPs were compared using one-way analysis of variance (ANOVA), with separation of means by Tukey's test $(p<0.05)$ when variance homogeneity was satisfied (Levene test, $p<0.05$ ).

\section{Results}

Healthy E. variegatus adults were used for the AAP on 10 FD-infected BBs, in which the phytoplasma concentration ranged from $1.16 \times 10^{4}$ to $2.96 \times 10^{5} \mathrm{FDP}$ GU/sample, with an average load of $9.71 \times 10^{4} \mathrm{FDP} \mathrm{GU} / \mathrm{sample}$. The results of qPCR tests on samples used for the transmission trials are presented in Table 1. Males and females were considered as a single group as no difference was found among the results from each sex in the same IAP. The presence of FDP in the leafhopper midgut was detected from IAP 1 at day 8 , and the infection rate in these organs reached $50 \%$, whereas in the salivary glands FDP was detected from IAP 2 at day 9 , with an infection rate gradually increasing 
and reaching its peak with $30 \%$ at IAP 7. As far as the BBs are concerned, FDP was detected from IAP 4 at day 11 with an infection rate reaching a maximum of $10 \%$ at day 14 (IAP 7). No significant difference between IAP levels was found by the GLM analysis either in the insect midguts or in BBs (E. variegatus: midguts $\chi^{2}=5.928 ; \mathrm{df}=6 ; p=0.431$; BBs: $\chi^{2}=10.819 ; \mathrm{df}=6 ; p=0.094$ ). In contrast, in salivary glands a significant increase in infection rates was recorded between IAP 1-4 groups and IAP 6 and 7 groups $\left(\chi^{2}=54.753 ; \mathrm{df}=6 ; p<0.001\right)$ (Table 1$)$. No insect with FD-positive salivary glands and negative midgut was found.

Table 1. Rate of flavescence dorèe phytoplasma infection in E. variegatus midgut and salivary glands after an acquisition access period at the adult stage, and in broad beans inoculated by single specimens. The number of infected samples for each group is indicated $(n=40)$. Different letters indicate significantly different results according to generalized linear model (GLM) analysis $(p<0.001)$.

\begin{tabular}{|c|c|c|c|c|c|c|}
\hline $\begin{array}{l}\text { Inoculation } \\
\text { Access } \\
\text { Period } \\
\text { (IAP) }\end{array}$ & $\begin{array}{c}\text { No. } \\
\text { Infected } \\
\text { Midguts }\end{array}$ & $\begin{array}{l}\text { Midgut Infection } \\
\text { Rate } \pm \mathrm{SE}^{1}\end{array}$ & $\begin{array}{c}\text { No. } \\
\text { Infected } \\
\text { Midguts + } \\
\text { Salivary } \\
\text { Glands }\end{array}$ & $\begin{array}{c}\text { Midgut + } \\
\text { Salivary } \\
\text { Glands } \\
\text { Infection } \\
\text { Rate } \pm \text { SE } 1\end{array}$ & $\begin{array}{c}\text { No. } \\
\text { Infected } \\
\text { BB }\end{array}$ & $\begin{array}{c}\text { Broad beans } \\
\text { Infection Rate } \pm \\
\text { SE }^{1}\end{array}$ \\
\hline 1 & 20 & $0.50 \pm 0.08$ n.s. ${ }^{2}$ & 0 & 0.00 & 0 & 0.00 \\
\hline 2 & 17 & $0.425 \pm 0.08$ n.s. ${ }^{2}$ & 4 & $0.10 \pm 0.04^{\mathrm{a}}$ & 0 & 0.00 \\
\hline 3 & 18 & $0.45 \pm 0.08$ n.s. ${ }^{2}$ & 6 & $0.15 \pm 0.06^{\mathrm{ab}}$ & 0 & 0.00 \\
\hline 4 & 12 & $0.30 \pm 0.07$ n.s. ${ }^{2}$ & 6 & $0.15 \pm 0.06^{\mathrm{ab}}$ & 1 & $0.03 \pm 0.02$ n.s. ${ }^{2}$ \\
\hline 5 & 13 & $0.325 \pm 0.07$ n.s. ${ }^{2}$ & 5 & $0.12 \pm 0.05^{\mathrm{ab}}$ & 2 & $0.05 \pm 0.03$ n.s. ${ }^{2}$ \\
\hline 6 & 17 & $0.425 \pm 0.08$ n.s. ${ }^{2}$ & 10 & $0.25 \pm 0.07^{b}$ & 3 & $0.08 \pm 0.04$ n.s. ${ }^{2}$ \\
\hline 7 & 19 & $0.475 \pm 0.08$ n.s. ${ }^{2}$ & 12 & $0.30 \pm 0.07^{b}$ & 4 & $0.10 \pm 0.05$ n.s. ${ }^{2}$ \\
\hline
\end{tabular}

${ }^{1}$ Standard Error according to the GLM output (SPSS Statistics); ${ }^{2}$ Not significant.

The E. variegatus infectivity rates ranged from $24 \%$ at IAP 2 to a maximum of $63 \%$ at IAP 7 , even though GLM analysis did not indicate significant differences $\left(\chi^{2}=9.751 ; \mathrm{df}=5 ; p=0.083\right)$ (Table 2). FISH experiments confirmed the presence of phytoplasmas in the insect midgut (Figure 2) and salivary glands (Figure 3) starting from IAP 2, consistently with qPCR results.

Table 2. Infectivity and transmission rates recorded for adult E. variegatus specimens after an AAP at the adult stage. The infectivity rates are calculated as the ratio between the insects with infected midgut + salivary glands (infective) and those with infected midgut (infected), as shown in Table 1. The transmission rate to broad beans was calculated as the ratio between the number of infected plants and infective E. variegatus specimens, as indicated in Table 1.

\begin{tabular}{|c|c|c|}
\hline IAP & E. variegatus Infectivity Rate $\pm \mathrm{SE}^{1}$ & E. variegatus Transmission Rate to $\mathrm{BB} \pm \mathrm{SE}^{1}$ \\
\hline 1 & Not Applicable (NA) & $\mathrm{NA}^{3}$ \\
\hline 2 & $0.24 \pm 0.11$ n.s. ${ }^{2}$ & $\mathrm{NA}^{3}$ \\
\hline 3 & $0.33 \pm 0.11$ n.s. ${ }^{2}$ & $\mathrm{NA}^{3}$ \\
\hline 4 & $0.50 \pm 0.15$ n.s. ${ }^{2}$ & $0.17 \pm 0.17$ n.s. ${ }^{2}$ \\
\hline 5 & $0.38 \pm 0.14$ n.s. ${ }^{2}$ & $0.40 \pm 0.24$ n.s. ${ }^{2}$ \\
\hline 6 & $0.59 \pm 0.12$ n.s. ${ }^{2}$ & $0.30 \pm 0.15$ n.s. ${ }^{2}$ \\
\hline 7 & $0.63 \pm 0.11$ n.s. ${ }^{2}$ & $0.33 \pm 0.14$ n.s. ${ }^{2}$ \\
\hline
\end{tabular}

${ }^{1}$ Standard Error according to the GLM output (SPSS Statistics); ${ }^{2}$ Not significant; ${ }^{3}$ Not Applicable. 


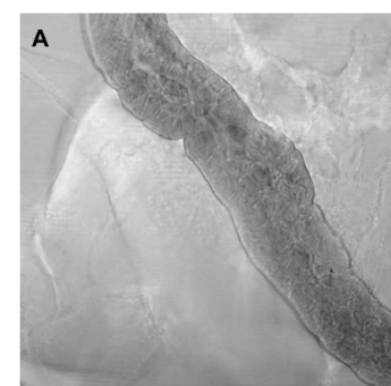

D

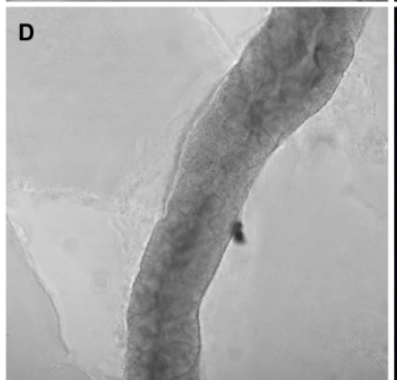

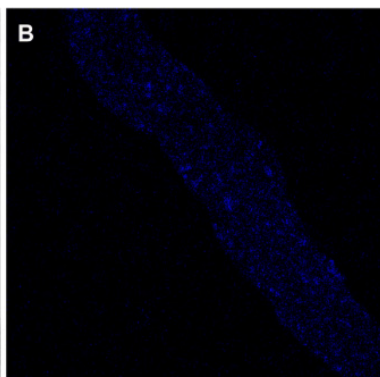

E

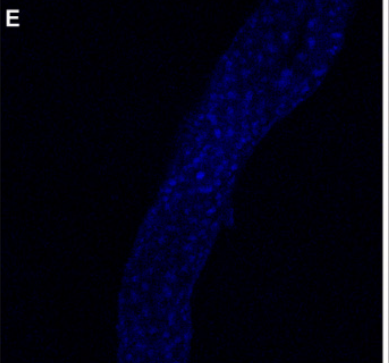

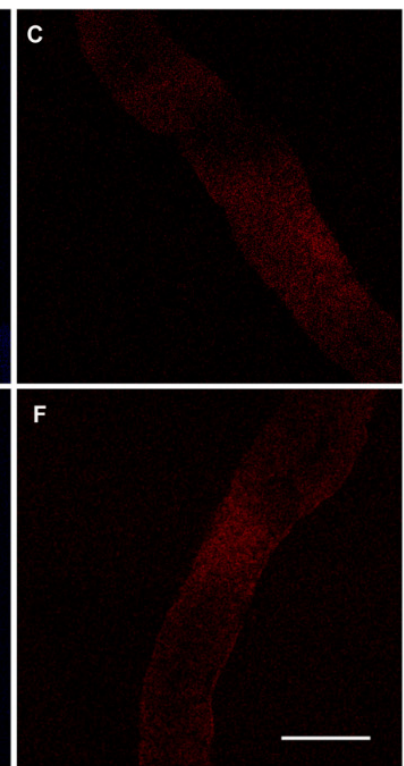

Figure 2. Whole mount fluorescence in situ hybridization on midgut samples from E. variegatus individuals after an AAP as adults. Exemplificative micrographs show the results corresponding to IAP 2 (A-C) and IAP 4 (D-F). Interferential contrast micrographs of the midguts are shown in (A) and (D); 4', 6-diamidino-2-phenylindole (DAPI) staining of midgut tissues is reported in (B) and (E); hybridization with the $16 \mathrm{SrV}$ phytoplasma-specific probe is shown in $(\mathbf{C})$ and $(\mathbf{F})$. Bar $=100 \mu \mathrm{m}$.

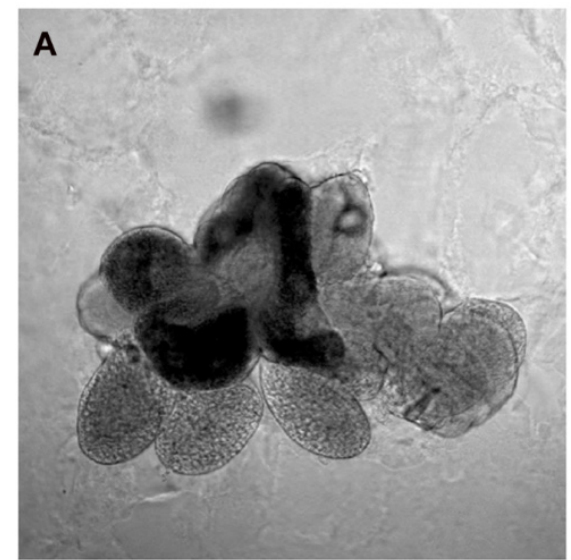

B

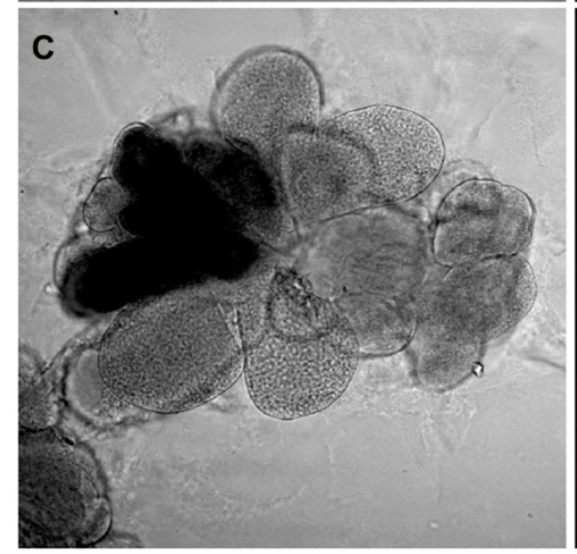

D

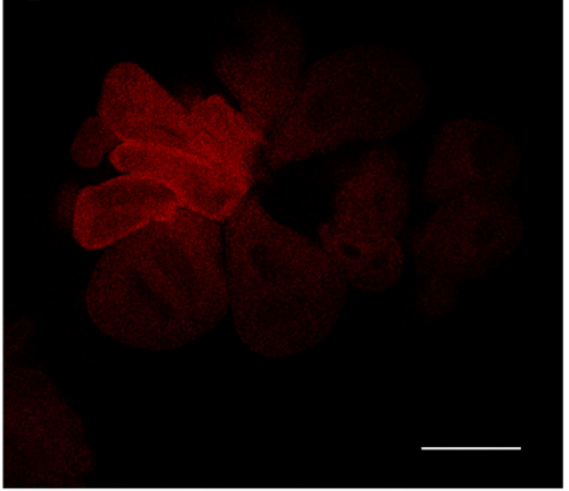

Figure 3. Whole mount fluorescence in situ hybridization on salivary glands from E. variegatus individuals after an AAP as adults. Exemplificative micrographs show the results corresponding to IAP $2(\mathbf{A}, \mathbf{B})$ and IAP 4 (C,D). Interferential contrast micrographs of the salivary glands are shown in (A) and (C), while hybridization with the $16 \mathrm{SrV}$ phytoplasma-specific probe is shown in (B) and (D). Bar $=150 \mu \mathrm{m}$. 
The ratio between positive BBs and infective leafhoppers (transmission rate) was 17\% at IAP 2 reaching $33 \%$ at IAP 7, again with no significance increment according to GLM $\left(\chi^{2}=1.015\right.$; $\mathrm{df}=3 ; p=0.798$ ) (Table 2). Furthermore, all of the FD-positive BBs were related to positive insects. One symptomatic plant was observed at IAP 4, and symptoms were recorded through the following IAP levels ( 1 out of 2 at IAP 5, 1 out of 3 at IAP 6 , and 2 out of 4 at IAP 7), whilst no symptoms were observed in plants used for IAP 1-3. All symptomatic plants tested positive by qPCR.

The average concentration of phytoplasma cells ranged from $5.78 \times 10^{2}$ to $9.86 \times 10^{4}$ FDP GU/sample in the leafhopper midgut, from $1.60 \times 10^{3}$ to $6.87 \times 10^{4}$ FDP GU/sample in the salivary glands, and from $3.29 \times 10^{0}$ to $1.16 \times 10^{2} \mathrm{FDP}$ GU/100 $\mathrm{mg}$ of plant tissue in inoculated BBs (Figure 4). In all sample groups, the IAP factor was not significant according to ANOVA (E. variegatus: midguts $\mathrm{df}=6,109 ; \mathrm{F}=0.957 ; p=0.458$; salivary glands $\mathrm{df}=5,37 ; \mathrm{F}=0.904 ; p=0.489 ; \mathrm{BBs}: \mathrm{df}=2,6 ; \mathrm{F}=1.793$; $p=0.245)$.

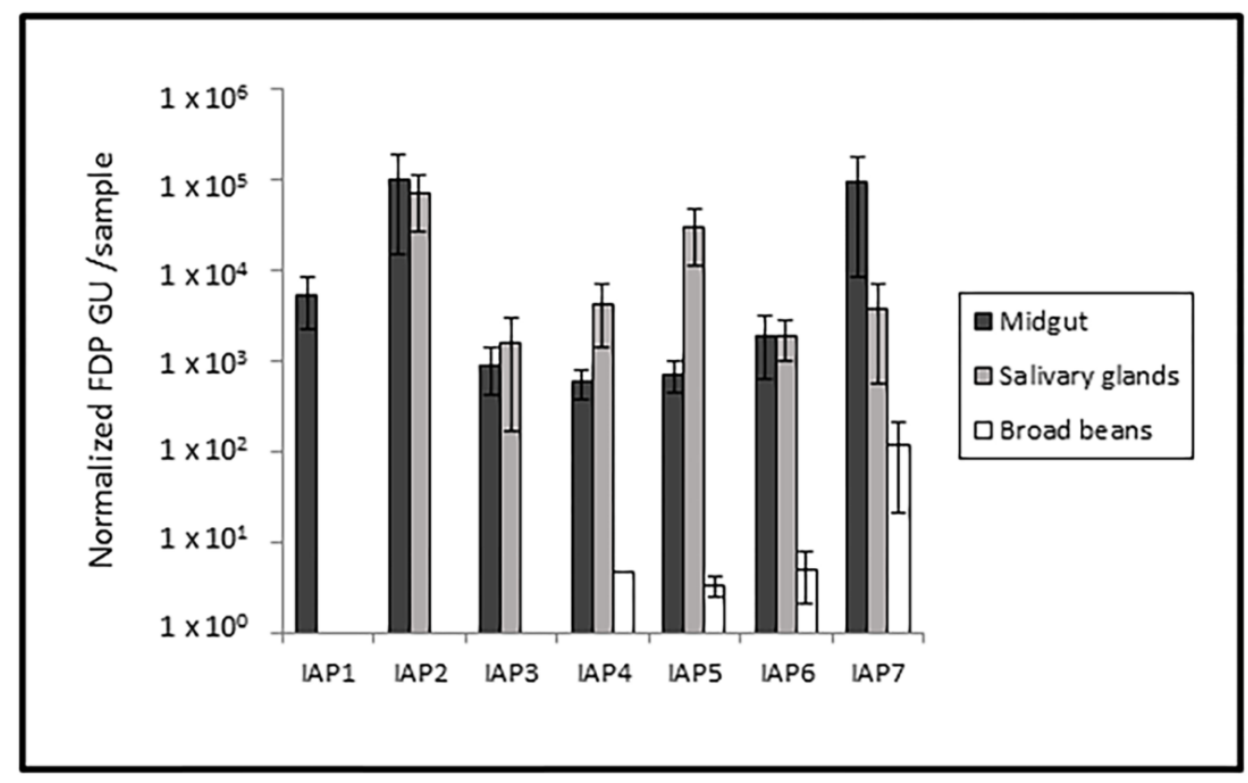

Figure 4. Average concentration of phytoplasma cells in midgut and salivary gland samples from FDP-positive E. variegatus corresponding to different IAPs, as well as in inoculated broad beans. Bars indicate the standard error.

\section{Discussion}

The present study provides evidence for the first time that E. variegatus is able to acquire and transmit FD-C phytoplasmas from infected BBs during the adult stage. This vector is routinely used to maintain FDP in broad beans under laboratory conditions [26] for investigating the details of the FDP cycle [25]. However, most of the data regarding the transmission of FD-related phytoplasmas by adult leafhoppers have been previously inferred from the S. titanus-FDP association. In S. titanus, nymphs from the third instar can acquire phytoplasmas by feeding on an infected host plant, and transmit them at the adult stage after 21 days (AAP + LP) [36-41]. Nonetheless, Galetto et al. [42] demonstrated that $S$. titanus is able to acquire FD-C phytoplasmas from infected broad beans as an adult as well. Recently, Alma et al. [19] highlighted that in S. titanus inoculation may take place in a shorter time (14 days) on broad beans under laboratory condition after an AAP as an adult.

In our experiments, adult E. variegatus became potentially infective after as little as 9 days from the beginning of the AAP, when FDP was first detectable in the salivary glands. Nonetheless, the observed temporal dynamics of phytoplasma colonization of salivary glands indicated that a relatively longer period could be required for FDP cells to stably settle in salivary glands, supporting an effective inoculation into plants, as demonstrated by the significant difference in the infection rates for these organs throughout the different performed IAPs. Consistently, successful inoculation occurred only at 
day 11, which still represented a very short LP. Under the same experimental conditions, nymphs of E. variegatus were previously demonstrated to be unable to transmit FDP to broad beans before 28 days $(\mathrm{AAP}+\mathrm{LP})$, even though the pathogen was detectable in the whole insect body as soon as 14 days from the beginning of the AAP [21]. The same vector successfully transmitted another phytoplasma, namely CYP, after an LP of 17-28 days starting from nymphs [21,43]. Since the time required for the colonization of E. variegatus salivary glands by FDP was reported to be slower at the nymphal stages than the time required by the co-evolved CYP [21], we can speculate that the LP occurring in adults may be even shorter for CYP. Furthermore, the high FDP titer and infection rate detected in the midgut as early as day 8 suggest an effective colonization of the intestine tissues by the phytoplasma, which reinforces this fast infection dynamics. Furthermore, the phytoplasma concentration in the insect vector was higher than what was obtained in S. titanus [19]. Moreover, previous reports indicated that, in nymphs of E. variegatus, more than 30 days are necessary for FDP to reach a concentration comparable to the titer recorded here from IAP 1 [21]. The long LP required by FDP in juveniles could be related to immune activation, especially in the hemocytes [23]. Since the number of circulating hemocytes in the hemolymph may be highly variable according to the insect life stage [44], a different immune response may be observed during phytoplasma infection in nymphs and adults of E. variegatus, allowing a faster colonization of adult individuals.

The phytoplasma load in the salivary glands did not vary significantly over a period of 14 days (7 days AAP + 7 days LP), indicating that in such a short time only limited pathogen multiplication takes place inside the leafhopper's body. Rather, a high phytoplasmal load is ingested by insects during the AAP. In case of AAP performed on nymphs, the minimum reported time required is $1 \mathrm{~h}$ for E. variegatus and Italian clover phyllody phytoplasma [45], while Bosco and Marzachì [24] reported $4 \mathrm{~h}$ for Macrosteles quadripunctulatus (Kirschbaum) and E. variegatus to acquire CYP. However, the AAP reported in the literature for most phytoplasma transmissions performed at nymphal instar ranges from a few to several days [24]. The LP also shows a wide range, from 12 days for C. tenellus and BLTV to over a month in other cases, as reviewed by Marzachì et al. [4]. Temperature was shown to influence the phytoplasma multiplication in the vector body [46], even if there is sometimes no clear correlation between phytoplasma titer and LP in the vector [47]. For example, high titers of the corn stunt spiroplasma are more rapidly reached in Dalbulus maidis (DeLong \& Wolcott) when multiplication starts from a higher load [48]. Therefore, the relatively high titer detected in the E. variegatus salivary glands might be due to a high level of FDP present in the BBs used for AAP.

It is generally believed that gender has an influence on phytoplasma acquisition and transmission $[8,10,11,49,50]$, since females are apparently more efficient than males. For example, sex-related differences in transmission efficiency were reported in vectors infected with phytoplasmas in the Aster Yellows group, probably because of their different behavior [4]. Our results seem to be in contrast to these previous studies since no difference between sexes was found, probably due to the very short LP needed by the adult leafhoppers.

The average percentage of phytoplasma-inoculated BBs was lower in our experiments than in a previous study involving S. titanus adults and FDP [19]; however, in that work, groups of five leafhoppers inoculated a single plant, increasing the chance of successful transmission. Conversely, taking into consideration the transmission rates, our results showed high efficiency in inoculating the BBs. Moreover, in our experiments the FDP load recorded in the plant was similar to the phytoplasma concentration reported by Alma et al. [19]; in both cases, this was low when compared with previous work [51]. Consistently, symptoms were observed only in some of the positive plants, probably because in some BBs the inoculated phytoplasma load was not sufficient to induce symptoms. This was likely due to the limited number of infected leafhoppers released on each plant during the IAP, one in the case of E. variegatus and five for S. titanus [19], suggesting that potential transmission efficiency could be even higher under different experimental conditions. 


\section{Conclusions}

Although the relationship between phytoplasma transmission and insect vectors has been widely studied to date, new insights are still arising to fill the remaining gaps. The ability of E. variegatus to acquire and transmit FDP during the adult stage with a short LP under laboratory conditions represents an important integration into the knowledge of phytoplasma transmission at the ecological and biological levels. These results complete and clarify what was previously reported by Alma et al. [19] for S. titanus, and they represent a relevant step to better explain phytoplasma epidemiology. Finally, increased awareness concerning the phytoplasma life cycle in the vector could support the implementation of new disease control methods.

Author Contributions: Conceptualization, L.P., E.G., and A.A.; methodology, L.P. and E.G.; software, L.P. and B.O.; validation, E.G. and A.A.; formal analysis, L.P., E.G., and A.A.; investigation, L.P., B.O., and M.M.; resources, A.A. and M.M.; data curation, L.P. and B.O.; writing-original draft preparation, L.P.; writing-review and editing, B.O., M.M., E.G., and A.A.; visualization, L.P., B.O., and E.G.; supervision, A.A.; project administration, E.G.; funding acquisition, A.A. and M.M. All authors have read and agreed to the published version of the manuscript.

Funding: This research received no external funding.

Acknowledgments: The authors are grateful to Giuseppe Galante and Enrico Busato for technical assistance.

Conflicts of Interest: The authors declare no conflict of interest.

\section{References}

1. Marcone, C. Molecular biology and pathogenicity of phytoplasmas. Ann. Appl. Biol. 2014, 165, $199-221$. [CrossRef]

2. Foissac, X.; Wilson, M.R. Current and possible future distributions of phytoplasma diseases and their vectors. In Phytoplasmas: Genomes, Plant Hosts and Vectors; CAB International: Wallingford, UK, 2010; pp. 309-324.

3. Seemüller, E.; Marcone, C.; Lauer, U.; Ragozzino, A.; Göschl, M. Current status of molecular classification of the phytoplasmas. J. Plant. Pathol. 1998, 80, 3-26.

4. Marzachì, C.; Milne, R.G.; Bosco, D. Phytoplasma-plant vector relationships. In Recent Research Development in Plant Pathology; Research Signpost: Trivandrum, Kerala, India, 2004; pp. 211-241.

5. Bertaccini, A.; Duduk, B.; Paltrinieri, S.; Contaldo, N. Phytoplasmas and phytoplasma diseases: A severe threat to agriculture. Am. J. Plant Sci. 2014, 5, 1763-1788. [CrossRef]

6. Purcell, A.H. Insect vector relationships with prokaryotic plant pathogens. Annu. Rev. Phytopathol. 1982, 20, 397-417. [CrossRef]

7. D'Arcy, C.; Nault, L.R. Insect transmission of plant viruses and mycoplasmalike and rickettsialike organisms. Plant Dis. 1982, 66, 99-104. [CrossRef]

8. Weintraub, P.G.; Beanland, L.A. Insect vectors of phytoplasmas. Annu. Rev. Entomol. 2006, 51, $91-111$. [CrossRef] [PubMed]

9. Alma, A.; Tedeschi, R.; Lessio, F.; Picciau, L.; Gonella, E.; Ferracini, C. Insect vectors of plant pathogenic Mollicutes in the European-Mediterranean region. Phytopathogenic Mollicutes 2015, 5, 53-73. [CrossRef]

10. Chiykowski, L.N.; Sinha, R.C. Sex and age of Macrosteles fascifrons in relation to the transmission of the clover proliferation causal agent. Ann. Entomol. Soc. Am. 1970, 63, 1614-1617. [CrossRef]

11. Swenson, K.G. Relation of age, sex and mating of Macrosteles fascifrons to transmission of aster yellows. Phytopathology 1971, 61, 657-659. [CrossRef]

12. Palermo, S.; Arzone, A.; Bosco, D. Vector-pathogen-host plant relationships of chrysanthemum yellows (CY) phytoplasma and the vector leahoppers Macrosteles quadripunctulatus and Euscelidius variegatus. Entomol. Exp. Appl. 2001, 99, 347-354. [CrossRef]

13. Carle, P.; Moutous, G. Observation sur le mode de nutrition sur vigne de quatre espèces de cicadelles. Ann. Epiphyt. 1965, 16, 333-354.

14. Hogenhout, S.A.; Oshima, K.; Ammar, E.D.; Kakizawa, S.; Kingdom, H.N.; Namba, S. Phytoplasmas: Bacteria that manipulate plants and insects. Mol. Plant. Pathol. 2008, 9, 403-423. [CrossRef]

15. Tsai, J.H. Plant and Insect mycoplasmas. In The Mycoplasmas, Vol. III.; Academic Press: Cambridge, MA, USA, 1979; pp. 265-307. 
16. Golino, D.A.; Oldfield, G.N.; Gumpf, D.J. Transmission characteristics of the beet leafhopper transmitted virescence agent. Phytopathology 1987, 77, 954-957. [CrossRef]

17. Chiykowski, L.N.; Sinha, R.C. Some factors affecting the transmission of eastern peach X- mycoplasmalike organism by the leafhopper Paraphlepsius irroratus. Can. J. Plant Pathol. 1988, 10, 85-92. [CrossRef]

18. Boudon-Padieu, E.; Larrue, J.; Caudwell, A. ELISA and dot-blot detection of Flavescence dorée-MLO in individual leafhopper vectors during latency and inoculative state. Curr. Microbiol. 1989, 19, 357-364. [CrossRef]

19. Alma, A.; Lessio, F.; Gonella, E.; Picciau, L.; Mandrioli, M.; Tota, F.C. New insights in phytoplasma-vector interaction: Acquisition and inoculation of flavescence dorée phytoplasma by Scaphoideus titanus adults in a short window of time. Ann. Appl. Biol. 2018, 173, 55-62. [CrossRef]

20. Koinuma, H.; Maejima, K.; Tokuda, R.; Kitazawa, Y.; Nijo, T.; Wei, W.; Kumita, K.; Miyazaki, A.; Namba, S.; Yamaji, Y. Spatiotemporal dynamics and quantitative analysis of phytoplasmas in insect vectors. Sci. Rep. 2020, 10, 1-13. [CrossRef]

21. Rashidi, M.; D'Amelio, R.; Galetto, L.; Marzachì, C.; Bosco, D. Interactive transmission of two phytoplasmas by the vector insect. Ann. Appl. Biol. 2014, 165, 404-413. [CrossRef]

22. Galetto, L.; Abbà, S.; Rossi, M.; Vallino, M.; Pesando, M.; Arricau-Bouvery, N.; Dubrana, M.-P.; Chitarra, W.; Pegoraro, M.; Bosco, D.; et al. Two phytoplasmas elicit different responses in the insect vector Euscelidius variegatus Kirschbaum. Infect. Immun. 2018, 86, e00042-18. [CrossRef] [PubMed]

23. Gonella, E.; Mandrioli, M.; Tedeschi, R.; Crotti, E.; Pontini, M.; Alma, A. Activation of immune genes in leafhoppers by phytoplasmas and symbiotic bacteria. Front. Physiol. 2019, 10, 795. [CrossRef]

24. Bosco, D.; Marzachì, C. Insect Transmission of Phytoplasmas. In Vector-Mediated Transmission of Plant Pathogens; The American Phytopathological Society: St. Paul, MN, USA, 2016; pp. 319-327.

25. Salar, P.; Charenton, C.; Foissac, X.; Malembic-Maher, S. Multiplication kinetics of Flavescence dorée phytoplasma in broad bean. Effect of phytoplasma strain and temperature. Eur. J. Plant Pathol. 2013, 135, 371-381. [CrossRef]

26. Miliordos, D.E.; Galetto, L.; Ferrari, E.; Pegoraro, M.; Marzachì, C.; Bosco, D. Acibenzolar-S-Methyl may prevent vector-mediated Flavescence dorée phytoplasma transmission, but is ineffective in inducing recovery of infected grapevines. Pest Manag. Sci. 2017, 73, 534-540. [CrossRef]

27. Caudwell, A.; Kuszala, C.; Larrue, J.; Bachelier, J.C. Transmission de la Flavescence dorée de la fève à la fève par des cicadelles des genres Euscelis et Euscelidius. Intervention possible de ces insectes dans l'épidémiologie du Bois noir en Bourgogne. Ann. Phytopathol. 1972, 181-189.

28. Marzachì, C.; Veratti, F.; Bosco, D. Direct PCR detection of phytoplasmas in experimentally infected insects. Ann. Appl. Biol. 1998, 133, 45-54. [CrossRef]

29. Marcone, C.; Ragozzino, A.; Schneider, B.; Lauer, U.; Smart, C.D.; Seemuller, E. Genetic characterization and classification of two phytoplasmas associated with spartium witches'-broom disease. Plant Dis. 1996, 80, 365-371. [CrossRef]

30. Marzachi, C.; Palermo, S.; Boarino, A.; Veratti, F.; d'Aquilio, M.; Loria, A.; Boccardo, G. Optimisation of a one-step PCR assay for the diagnosis of Flavescence dorée related phytoplasmas in field-grown grapevines and vector populations. VITIS 2001, 40, 213-217.

31. Galetto, L.; Bosco, D.; Marzachì, C. Universal and group-specific real-time PCR diagnosis of flavescence dorée (16Sr-V), bois noir (16Sr-XII) and apple proliferation (16Sr-X) phytoplasmas from field-collected plant hosts and insec vectors. Ann. Appl. Biol. 2005, 147, 191-201. [CrossRef]

32. Schneider, B.; Seemuller, E. Presence of 2 sets of ribosomal genes in phytopathogenic Mollicutes. Appl. Envir. Microbiol. 1994, 60, 3409-3412. [CrossRef]

33. Marzachì, C.; Bosco, D. Relative quantification of chrysanthemum yellows (16Sr I) phytoplasma in its plant and insect host using real-time polymerase chain reaction. Mol. Biotech. 2005, 30, 117-127. [CrossRef]

34. Lessio, F.; Picciau, L.; Gonella, E.; Mandrioli, M.; Tota, F.; Alma, A. The mosaic leafhopper Orientus ishidae: Host plants, spatial distribution, infectivity, and transmission of $16 \mathrm{SrV}$ phytoplasmas to vines. Bull. Insectol. 2016, 69, 277-289.

35. Gonella, E.; Negri, I.; Marzorati, M.; Mandrioli, M.; Sacchi, L.; Pajoro, M.; Crotti, E.; Rizzi, A.; Clementi, E.; Tedeschi, R.; et al. Daffonchio, D. Bacterial endosymbiont localization in Hyalesthes obsoletus, the insect vector of Bois noir in Vitis vinifera. Appl. Environ. Microbiol. 2011, 77, 1423-1435. [CrossRef] [PubMed] 
36. Schvester, D.; Carle, P.; Moutous, G. Transmission de la Flavescence dorée de la vigne par Scaphoideus littoralis Ball, (Homopt. Jassidae). Ann. Epiphyties 1961, 14, 175-198.

37. Schvester, D.; Carle, P.; Moutous, G. Nouvelles données sur la transmission de la Flavescence dorée de la vigne par Scaphoideus littoralis Ball. Ann. Zool. Écol. An. 1969, 1, 445-465.

38. Caudwell, A.; Kuszala, C.; Bachelier, J.C.; Larrue, J. Transmission of the golden flavescence of vines to herbaceous plants by the prolongation of the time during which S. littoralis can be used and the study of its survival on a large number of plant species. Ann. Phytopathol. 1970, 2, 415-428.

39. Bressan, A.; Spiazzi, S.; Girolami, V.; Boudon-Padieu, E. Acquisition efficiency of Flavescence doree phytoplasma by Scaphoideus titanus Ball from infected tolerant or susceptible grapevine cultivars or experimental host plants. Vitis 2005, 44, 143-146.

40. Lessio, F.; Tedeschi, R.; Alma, A. Presence of Scaphoideus titanus on American grapevine in woodlands, and infection with "flavescence doree" phytoplasmas. Bull. Insectol. 2007, 60, 373-374.

41. Chuche, J.; Thiery, D. Biology and ecology of the Flavescence doree vector Scaphoideus titanus: A review. Agron. Sust. Devel. 2014, 34, 381-403. [CrossRef]

42. Galetto, L.; Miliordos, D.; Roggia, C.; Rashidi, M.; Sacco, D.; Marzachi, C.; Bosco, D. Acquisition capability of the grapevine Flavescence doree by the leafhopper vector Scaphoideus titanus Ball correlates with phytoplasma titre in the source plant. J. Pest Sci. 2014, 87, 671-679. [CrossRef]

43. Bosco, D.; Galetto, L.; Leoncini, P.; Saracco, P.; Raccah, B.; Marzachì, C. Interrelationships between “Candidatus Phytoplasma asteris" and its leafhopper vectors (Homoptera: Cicadellidae). J. Econ. Entomol. 2007, 100, 1504-1511. [CrossRef]

44. Strand, M.R. The insect cellular immune response. Insect Sci. 2008, 15, 1-14. [CrossRef]

45. Carraro, L.; Loi, N.; Gregoris, A.; Ermacora, P.; Osler, R. Studies on the transmission of a phytoplasma from Chrysanthemum leucanthemum L. by the leafhopper Euscelidius variegatus Kbm. IOM Lett. 1996, 4, 127-128.

46. Murral, D.J.; Nault, L.R.; Hoy, C.W.; Madden, L.V.; Miller, S.A. Effects of temperature and vector age on transmission of two Ohio strains of aster yellows phytoplasma by the aster leafhopper (Homoptera: Cicadellidae). J. Econ. Entomol. 1996, 89, 1223-1232. [CrossRef]

47. Galetto, L.; Marzachì, C.; Marques, R.; Graziano, C.; Bosco, D. Effects of temperature and CO2 on phytoplasma multiplication pattern in vector and plant. Bull. Insectol. 2011, 64, S151-S152.

48. Alivizatos, A.S.; Markham, P.G. Acquisition and transmission of corn stunt spiroplasma by its leafhopper vector Dalbulus maidis. Ann. Appl. Biol. 1986, 108, 535-544. [CrossRef]

49. Chapman, R.K. Some Factors Affecting the Transmission of Aster-Yellows Virus by the Six-Spotted Leafhopper, Macrosteles divisus (UHL.). Ph.D. Thesis, University of Wisconsin, Madison, WI, USA, 1949.

50. Beanland, L.; Hoy, C.W.; Miller, S.A.; Nault, L.R. Leafhopper transmission of the aster yellows phytoplasma: Does sex matter? Environ. Entomol. 1999, 28, 1101-1106. [CrossRef]

51. Galetto, L.; Miliordos, D.; Pegoraro, M.; Sacco, D.; Veratti, F.; Marzachì, C.; Bosco, D. Acquisition of Flavescence dorée phytoplasma by Scaphoideus titanus Ball from different grapevine varieties. Int. J. Mol. Sci. 2016, 17, 1563. [CrossRef]

(C) 2020 by the authors. Licensee MDPI, Basel, Switzerland. This article is an open access article distributed under the terms and conditions of the Creative Commons Attribution (CC BY) license (http://creativecommons.org/licenses/by/4.0/). 